\title{
Diplomacy and Trade: The Current Contradictory Relations between the United States and Bolivia
}

\author{
Erick D. Langer \\ Georgetown University
}

\begin{abstract}
Diplomatic relations between Bolivia and the United States have been difficult since Evo Morales became president in 2006. Despite these poor relations and even despite the abrogation of the ATPDEA (Andean Trade Promotion and Drug Eradication Act) in 2008, commerce between Bolivia and the United States has increased more than during governments allied with the United States. These conclusions show that the state of diplomatic relations are not necessarily indicative of the intensity of trade between countries.
\end{abstract}

\section{Keywords}

ATPDEA, Evo Morales, International commerce, diplomatic relations

\section{Resumen}

Las relaciones diplomáticas entre Bolivia y Estados Unidos han sido complicadas desde que Evo Morales ascendió a la presidencia en 2006. No 
obstante las malas relaciones diplomáticas, aun con la abrogación de la ATPDEA (Ley de Preferencias Arancelarias Andinas y Erradicación de la Droga), el comercio entre Bolivia y Estados Unidos ha incrementado más que con gobiernos aliados con Estados Unidos. Estas conclusiones muestran que el estado de las relaciones diplomáticas no determina necesariamente la intensidad del comercio entre países.

Palabras claves

ATPDEA, Comercio internacional, Evo Morales, relaciones diplomáticas

Despite the fact that Bolivia is a relatively small country in South America, relations between Bolivia and the United States have since the mid-twentieth century been intense and have mattered to both countries more than the relative size of each country suggests. Indeed, commercial relations in the twenty-first century have been increasing, though the diplomatic deep freeze in relations since the Evo Morales administration did not let up.

Milton Eisenhower's visit to Bolivia in 1953 created the ties between Bolivia and the United States that lasted until Evo Morales's election in 2005. Eisenhower was impressed by President Víctor Paz Estenssoro, who persuaded the U.S. president's brother that the United States should support the drastic changes that the MNR--Movimiento Nacionalista Revolucionario-government had implemented. As James Siekmeier has shown, Bolivian Ambassador Víctor Andrade was also crucial to this effort. For the only time, the United States supported a social revolutionary regime in Latin America, providing needed food to the cities while the Bolivian countryside was still in flames. ${ }^{1}$ After that, Bolivia became the largest recipient of U.S. aid, as Paz Estenssoro also forged close relations with the Kennedy administration and its Alliance for Progress. To a large extent, Bolivia became the poster child of the Alliance, showing how the U.S. government supported "reasonable" social change without resorting to Communism. ${ }^{2}$

\footnotetext{
${ }^{1}$ Kenneth D. Lehman, Bolivia and the United States: A Limited Partnership, 103-113; James F. Siekmeier, The Bolivian Revolution and the United States, 1952 to the Present, 42-72.

2 James W. Wilkie, The Bolivian Revolution and U.S. Aid Since 1952: Financial Background and Context of Political Decisions.
} 
Thereafter, the U.S. Embassy in Bolivia remained an important factor in national politics. Ambassadors had the power to affect governments, as was the case when Edwin G. Corr (1980-1985) helped to push dictator General Luis García Meza (1980-1981) out of office and reestablish democracy. Indeed, by the 1990s the U.S. Embassy played an increasingly important role, with a large USAID presence and a very active Drug Enforcement Agency. ${ }^{3}$ This was especially the case under General Hugo Banzer, after he had changed from military dictator (1970-1978) to the leader of a right-wing party, Acción Democrática Nacionalista, and, in alliance with a center-left party, was elected president (1997-2001). Banzer adopted a severe coca eradication program that mobilized the coca growers' unions, of which Evo Morales was a leader. ${ }^{4}$

By the early 2000s, leftists intensified their accusations that the United States had an undue influence in Bolivian politics. President Gonzalo Sánchez de Lozada (1993-7, 2002-3), a technocrat and wealthy mine owner, was especially susceptible to these accusations, as he had lived many years in the United States and had a strong English accent when he spoke Spanish. "Goni," as he was known, also implemented a series of neo-liberal reforms that diminished the size of the state and sold controlling interests of many state-owned corporations to foreign companies. Some people saw the U.S ambassador as a "Viceroy," who helped determine Bolivian government policy. ${ }^{5}$

The large influence of the United States inevitably brought with it a nationalist reaction. This was especially the case in the 2002 elections, when U.S. Ambassador Manuel Rocha infamously stated just three days before the elections that the United States would not look kindly upon the election of candidate Evo Morales because of his ties to the coca growers' union ${ }^{6}$ Morales, who had been in fourth place at $11 \%$ in electoral surveys, in the election surged to almost $21 \%$, the same number of votes that of Manfred Reyes Villa, who had

3 Amado Canelas Orellana and Juan Carlos Canelas Zannier, Bolivia--Coca Cocaina: Subdesarrollo y poder Político.

${ }^{4}$ There are many publications on this point. See for example Ellen C. Leichtman, "Bolivia, Coca and U.S. Foreign Policy." 63-84. https://doi.org/10.1007/BF02461038

5 See for example Luis A. Gómez, "Los últimos milagros del Virrey Manuel Rocha." Voltaire.net, July 17, 2002. http://www.voltairenet.org/article120450.html

${ }^{6}$ Duncan Campbell, "Bolivia's Leftwing Upstart Alarms US.” The Guardian, July 14, 2002. https://www.theguardian.com/world/2002/jul/15/usa.duncancampbell 
been in second place. (Goni received $22.5 \%$ of the vote and, after much wheeling and dealing, became president again). ${ }^{7}$

Despite the fact that the 2002 elections made Morales into a serious electoral contender (thanks to Ambassador Rocha), Morales saw Bolivia as too dependent on the United States and ran successfully on a leftist-nationalist platform. The feeling of mistrust between the United States and Morales was mutual. Indeed, after Morales assumed the office of president in 2006, he railed against the influence of the United States in his fight against the eastern lowland regions that had largely voted against him.

In 2008, the Bolivian president expelled both U.S. Ambassador Philip Goldberg and the Drug Enforcement Agency from the country. Bolivia expelled the ambassador in solidarity with Venezuela's expulsion of the U.S. ambassador there, though factions within the Morales administration had pushed for this action even before Venezuelan president Hugo Chávez made his move. In retaliation, the Bush administration suspended Bolivia's access to the Andean Trade Promotion and Drug Eradication Act (ATPDEA) the following year. The ATPDEA, which in addition to Bolivia, included Colombia, Ecuador, and Peru, was conceived to aid the Andean countries' formal economies as a means of combating drug trafficking. The original idea, conceived in 2002, was that providing favored access to U.S. markets for legitimate exports would lead to the strengthening of the formal sector and lead to less dependence on illegal drugs in the Andean economies. Both the Bush and the Obama administrations refused to continue to include Bolivia, arguing that it had not done enough to eradicate coca plantings or diminish cocaine exports. ${ }^{8}$

The continued decertification of Bolivia by the United States in its drug control efforts also meant that the two countries did not achieve a diplomatic defrosting. The new Assistant Secretary of State of the Western Hemisphere under the Obama administration, Arturo Valenzuela (2009-2011), had tried to make possible a resumption of diplomatic relations based on a document that asserted the mutual respect that each country would maintain for each other. However, elements in the Morales government were not in favor of a

\footnotetext{
7 Rodrigo Salazar Elena, "Las elecciones bolivianas de 2002: Los límites del reformismo institucional." Revista Mexicana de Sociología, 23-56.

8 "Diputados amplían el ATPDEA; Bolivia sigue suspendida," La Razón, September 30, 2008. Also see U.S. International Trade Commission, Andean Trade Preference Act: Impact on U.S. Industries and Consumers and on Drug Crop Eradication and Crop Substitution, 2013. Sixteenth Report.

https://www.usitc.gov/publications/332/pub4486_0.pdf
} 
reestablishment of ties and the continued decertification of Bolivia for not doing enough against the drug trade stymied these efforts. For Evo Morales, who remained the head of the coca growers' union even as he became president, it was difficult politically to do much - even if he had wanted to - to work against the coca growers. The United States did not want to recognize the Morales administration's efforts to "industrialize" the coca leaf for non-drug use and thus justify the planting of coca at high levels. The expulsion of the U.S Agency for International Development followed in 2013, when President Morales on May Day accused the agency of political interference. ${ }^{9}$ In addition, Evo Morales continued to tweet messages and give speeches that accused the United States of imperialism and other nefarious deeds. Morales's support of the governments of Cuba and of Venezuela, given the increasingly harsh rhetoric and actions against these two regimes by the Trump administration also provided little hope that diplomatic relations will improve.

Despite the tense political relations, the disappearance of ATPDEA and the absence of ambassadorial-level relations, Bolivia and the United States continued to increase trade ties. This was in part due to the commodities boom, in which Bolivia participated. For the United States, this included in particular minerals such as tin from the abundant Bolivian mines. In 2016, Bolivia exported to the United States $\$ 979$ million worth of goods. Trade with the United States was second only to Brazil, which was number one because it received natural gas, Bolivia's most important export. ${ }^{10}$ Trade with the United States accelerated markedly over the twenty-first century; on average Bolivian exports to the United States for the decade of 2008 to 2017 was almost five times higher than the decade from $1992-2001 .^{11}$ (See Fig. 1)

\footnotetext{
9 "Evo expulsa a Usaid de Bolivia tras acusarla de injerencia política." La Razón, May 2, 2013. http://www.la-razon.com/economia/Evo-Usaid-Bolivia-injerenciapolitica_0_1825617424.html. Also see Lawrence C. Heilman, USAID in Bolivia: Partner or Patrón? (2017).

10 See OEC (The Observatory of Economic Complexity) https://atlas.media.mit.edu/es/profile/country/bol/

11 "Trade in Goods with Bolivia." U.S. Census Bureau. https://www.census.gov/foreigntrade/balance/c3350.html
} 


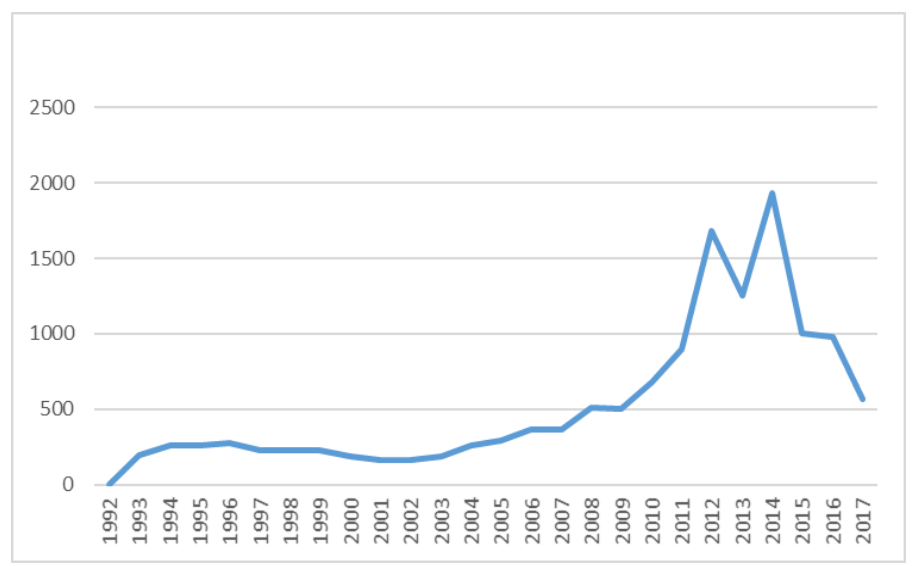

Figure 1: Bolivian Exports to the United States, 1992-2017 Source: "Trade Goods in Bolivia." U.S. Census Bureau

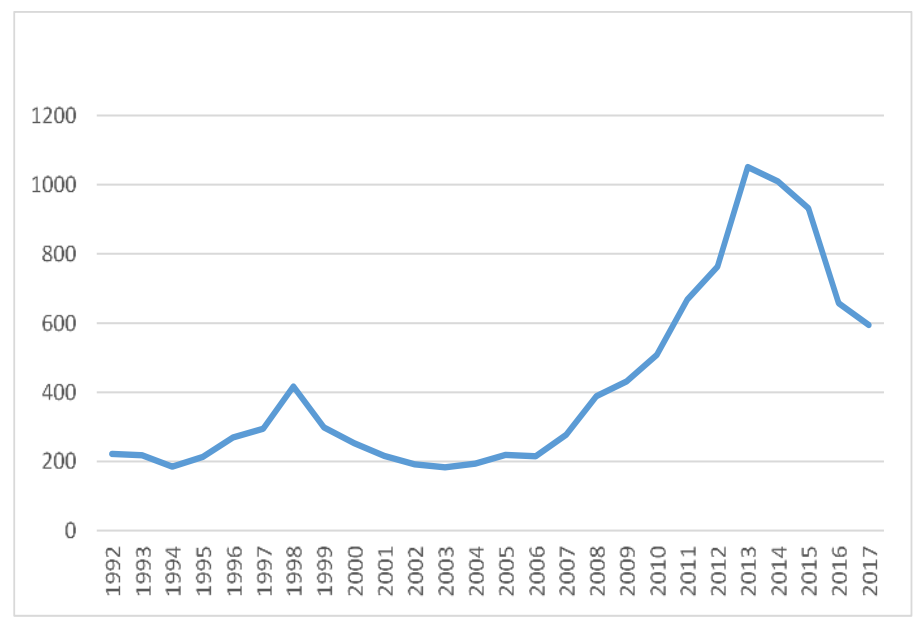

Figure 2: Imports to Bolivia from the United States, 1992-2017

Source: "Trade Goods in Bolivia." U.S. Census Bureau https://www.census.gov/foreign-trade/balance/c3350.html 
In 2016, the United States was the fourth largest importer into Bolivia, after China, Brazil, and Chile, with a total of $\$ 810$ million of imports. ${ }^{12}$ As in the case of exports to the United States, imports from the United States increased markedly from around 2007 onward, only to decline somewhat over the past two years. The United States had a perpetual trade deficit with Bolivia, but imports to Bolivia roughly followed those of Bolivian exports, though lagging somewhat behind the former. (Fig. 2)

Bolstering this trade, Bolivia and the United States signed on July 6, 2017 a Customs Mutual Assistance Agreement (CMAA), which provides for cooperation between the customs agencies of the two countries. ${ }^{13}$ The United States has CMAAs with 79 different countries, about half the world. A CMAA with Bolivia shows the importance of trade relations between the two countries, even in the absence of regular diplomatic relations. ${ }^{14}$

Remittances showed a similar pattern - a sharp increase beginning after 2007 in percentage terms. Remittances hit a maximum in 2007, with $8 \%$ of total GDP. By 2016, remittances had declined to $3.6 \%$ of GDP, but at much higher rates than earlier. ${ }^{15}$ In absolute numbers, this translated into different figures because of economic growth in Bolivia, which experienced rapid growth during the commodities boom. Thus, after 2007, remittances from throughout the world only once went lower than a billion dollars (2010), though the percentage of GDP decreased despite the amount of remittances remaining relatively stable. (Fig. 3)

The United States was third in remittances, after Argentina and Spain. In 2016, migrants from the United States contributed \$148 million, topped by

\footnotetext{
12 See OEC (The Observatory of Economic Complexity) https://atlas.media.mit.edu/es/profile/country/bol/

13 "United States Signs Customs Mutual Assistance Agreements with Bolivia and Georgia." U.S. Customs and Border Protection website.

https://www.cbp.gov/newsroom/national-media-release/united-states-signs-customsmutual-assistance-agreements-bolivia-and

${ }^{14}$ See also Iván Paredes Tamayo, "Agoniza la relación política Bolivia-EEUU, pero los negocios bilaterales, en ascenso." El Deber, "Séptimo Día” Section, July 1, 2018. https://www.eldeber.com.bo/septimodia/Relacion-politica-Bolivia-EEUU-agonizapero-no-los-negocios-bilaterales-20180629-6519.html

15 "Remittance Inflows to GDP for the Plurinational State of Bolivia." FRED: Economic Research, Federal Reserve Bank of St. Louis, https://fred.stlouisfed.org/series/DDOI11BOA156NWDB
} 
Argentina (\$629 million) and Spain (\$271 million). ${ }^{16}$ Despite the world economic downturn beginning in 2008, Bolivian migrants continued to send money to their home country in record numbers.

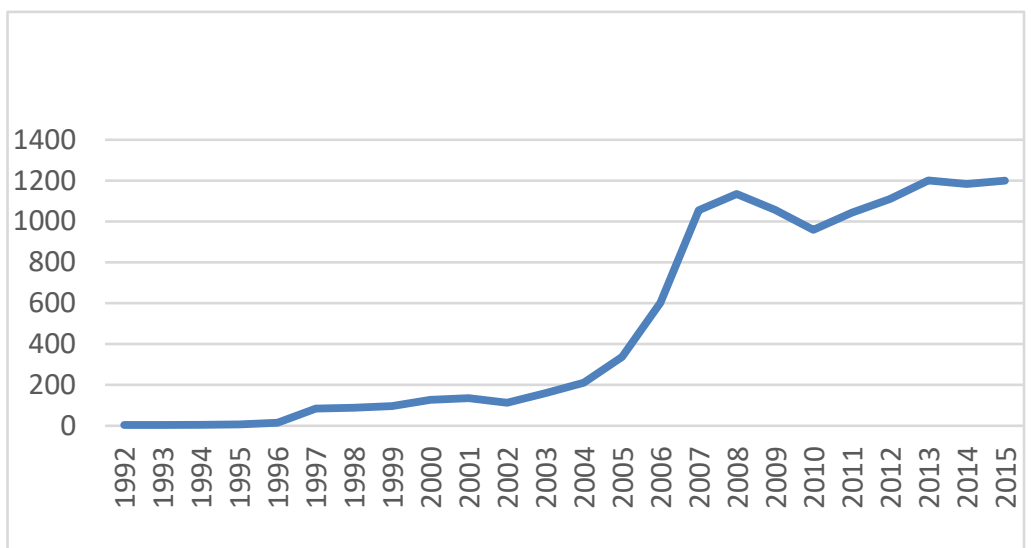

Figure 3: Remittances to Bolivia (World), 1992-2015

Source: "Remittances to Bolivia - 1970 to 2015"

USD Explorer, http://www.usdexplorer.com/remittances-to-Bolivia/

\section{Conclusions}

In all, relations between Bolivia and the United States have been different than the diplomatic impasse would have suggested. On an economic level, relations intensified especially after Evo Morales's first term of office (2006-2011). This was in part due to the commodities boom that the integration of China into the World Trade Organization brought about, though the increase in commercial relations between the two countries occurred well into the boom period, which began around the turn of the century. In relative terms, the United States has, of course, lost its preeminence with the irruption of China on the commercial scene. While Brazil and Argentina with the United States have traditionally been the most important partners with Bolivia as the destination of its products, today China is the largest importer of goods for

\footnotetext{
16 "Bolivia: Migrant remittance." countryeconomy.com

https://countryeconomy.com/demography/migration/remittance/bolivia
} 
Bolivia. This has meant, just like in much of the rest of South America that Bolivia has not had to rely on the United States as much as previously. It provided the Morales administration, as with many other Latin American governments, much more political wiggle room as the absolute commercial hegemony of the United States has disappeared in the hemisphere. It appears that commercial relations can intensify despite the lack of diplomatic relations. Perhaps the lack of diplomatic relations in fact was beneficial to the less powerful country, as the United States could not use its Embassy as it did in the past to provide more favorable treatment for its companies and products to the detriment of its consumers and exporters.

\section{Works Cited}

"Bolivia: Migrant remittance." countryeconomy.com.

[https://countryeconomy.com/demography/migration/remittance/boli vial downloaded Nov. 22, 2019.

CAMPBELL, Duncan. 2002. "Bolivia's Leftwing Upstart Alarms US." The Guardian 14 July. [https://www.theguardian.com/world/2002/jul/15/usa.duncancampb ell] downloaded Nov. 22, 2019.

CANELAS ORELLANA, Amado and Juan Carlos Canelas Zannier. 1983. Bolivia: Coca Cocaina: Subdesarrollo y poder político. La Paz: Los Amigos del Libro.

“Diputados amplían el ATPDEA; Bolivia sigue suspendida." 2008. La Razón 30 Sept.

"Evo expulsa a Usaid de Bolivia tras acusarla de injerencia política." 2013. La Razón 2 May. [http://www.la-razon.com/economia/Evo-Usaid-Boliviainjerencia-politica_0_1825617424.html] downloaded Nov. 22, 2019.

GÓMEZ, Luis A. “Los últimos milagros del Virrey Manuel Rocha.” 2019. Voltairenet.org. July 17 [http://www.voltairenet.org/article120450.html] downloaded Nov. 22, 2019.

HEILMAN, Lawrence C. 2017. USAID in Bolivia: Partner or Patrón? Boulder, CO: First Forum Press.

LEHMAN, Kenneth D. 1999. Bolivia and the United States: A Limited Partnership. Athens, GA: University of Georgia Press.

LEICHTMAN, Ellen C. 2000. "Bolivia, Coca and U.S. Foreign Policy." Critical Criminology 9(1-2): 63-84, [https://doi.org/10.1007/BF02461038] downloaded Nov. 22, 2019.

OEC (The Observatory of Economic Complexity). 2017. Bolivia. [http://atlas.media.mit.edu/es/profile/country/bol/] Downloaded Nov. 22, 2019. 
PAREDES TAMAYO, Iván. 2018. "Agoniza la relación política Bolivia-EEUU, pero no los negocios bilaterales." El Deber. "Séptimo Día" Section, 1 July. [https://www.eldeber.com.bo/septimodia/Relacion-politicaBolivia-EEUU-agoniza-pero-no-los-negocios-bilaterales-201806296519.html] downloaded Nov. 22, 2019.

"Remittance Inflows to GDP for the Plurinational State of Bolivia." 2019. FRED: Economic Research, Federal Reserve Bank of St. Louis. [https://fred.stlouisfed.org/series/DDOI11BOA156NWDB] downloaded Nov. 22, 2019.

"Remittances to Bolivia - 1970 to 2015." USD Explorer.

[http://www.usdexplorer.com/remittances-to-Bolivia/] downloaded Nov. 22, 2019.

SALAZAR ELENA, Rodrigo. 2004. "Las elecciones bolivianas de 2002: Los límites del reformismo institucional." Revista Mexicana de Sociología 66(1): 23-56.

SIEKMEIER, James F. 2011. The Bolivian Revolution and the United States, 1952 to the Present. University Park, PA.: Pennsylvania State University Press.

"Trade in Goods with Bolivia." U.S. Census Bureau. [https://www.census.gov/foreign-trade/balance/c3350.html] downloaded Nov. 22, 2019.

U.S. INTERNATIONAL TRADE COMMISSION. 2013. Andean Trade Preference Act: Impact on U.S. Industries and Consumers and on Drug Crop Eradication and Crop Substitution, 2013. Sixteenth Report. [https://www.usitc.gov/publications/332/pub4486_0.pdf] downloaded Nov. 22, 2019.

"United States Signs Customs Mutual Assistance Agreements with Bolivia and Georgia." [https://www.cbp.gov/newsroom/national-mediarelease/united-states-signs-customs-mutual-assistance-agreementsbolivia-and] downloaded Nov. 22, 2019.

WILKIE, James W. 1969. The Bolivian Revolution and U.S. Aid Since 1952: Financial Background and Context of Political Decisions. Latin American Studies vol. 13. Los Angeles: Latin American Center, University of California.

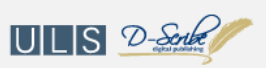

New articles in this journal are licensed under a Creative Commons Attribution 4.0 United States License.

This journal is published by the University Library System of the University of Pittsburgh as part of its D-Scribe Digital Publishing Program, and is cosponsored by the University of Pittsburgh Press. 